\title{
The School Administration Roles In The Implementation of Computer Based Test - National Examination In East Aceh, Aceh, Indonesia
}

\author{
Dara Iffah \\ International Islamic University Malaysia (IIUM) \\ Sajedeh Divan Pour \\ School of Language, \\ Asre Gooya English Institute Maheshaher, Iran \\ Mushtaq Ahmad \\ Tenga Nasional University Malaysia, \\ Uniten Kajang Malaysia
}

\begin{abstract}
The purpose of this study is to find out to what extent school administration in East Aceh administered the CBT-NE are ready for accepting Computer Based National Examination (CBNE) in terms of its objective, infrastructure and human resource management, budget allocated management and management of examination. This study employed a qualitative case study approach consisting of three schools from three distinct categories such as general secondary school, secondary boarding school and vocational school in East Aceh District. All the selective schools have implemented the CBT-NE system for students. For collecting data, the researcher conducted interviews with the selected schools' principals. The research findings report on the variety of preparation that these three schools had taken in implementing CBNE. In terms of infrastructure and human resource management, they followed the instruction provided by the Ministry of Education, Indonesia, while there is also additional equipment that they prepared as well to maintain the electric supply. Moreover, schools got both financial and non-financial supports from the government that allocated to purchase and repair the computer, and honorarium in CBT-NE in their schools. In terms of management role, the schools conducted training for students and teachers to manage the session and community involvement in conducting CBNE.
\end{abstract}

Key Words: Computer based Test (CBT), National Examination, Schools and Education, Indonesia

\section{INTRODUCTION}

National examination (NE) is a mandate of the Law on the National Education System No. 20/2003 and also a mandate of Government Regulation of the Republic of Indonesia No. $19 / 2005$ that was revised into No. 32/2013 and No. 13/2015 concern on National Education Standard (Kemendikbud RI, 2016). Based on those regulations, National Education Standard is the minimum criteria for the educational system in the entire territory of the Unitary Republic of Indonesia. The purpose of NE is to measure the competence of graduates in subjects at the national level according to the Competency Standards Graduates. In addition, NE is a subsystem of assessment in the National Education Standards that has become a benchmark in order to guarantee the achievement of the National Education Standards and also to improve the quality of education (Kemendikbud, 2016). In this case, there are three aims of NE implementation; to map the quality of program or educational unit, as the basic of selection 
that can be used to the next education level, and for the development and provision of assistance to the educational unit in its efforts to improve the quality of education (Baswedan, 2015).

In 2005, National Examination was established a a reformed of Final National Examination. The system was still the same and the minimum mean score increased to 4.25. This similar system has been continuing till now where the minimum score 5.50 and integrating minimum score is 7.00 (Nurfuadah, 2014). Since its implementation in 2005, NE leads issues in education system. Fraud cases is become the main issue that occured in most of provinces in Indonesia every year of its implementation. There are a lot number of schools committed into fraud in order to reduce the number of students who fail in the examination. Meanwhile, in order to achieve the mandate of education regulation of Indonesia, the Ministry of Education in Indonesia expected to maintain the secrecy of the examination and the integrity of examination. As the result, MoE of Indonesia established the computer based system exam in NE.

\section{Aim of Study}

This study aims at identifying the readiness of schools in terms of facilities, infrastructure, leadership and administration for implementing Computer Based National Examination. This study is conducted in selected secondary high schools in east Aceh distric, Aceh province that have implemented Computer Based Examination in 2016.

\section{Integrating Computer Based Assessment}

\section{LITERATURE REVIEW}

Computer-based assessment is a method to administer an examination in which the responses are recorded, and assessed electronically (Joshua and Ikiroma, 2012). The implementation of Computer in Assessment brings benefits in tems of reducing paper use for examination booklet, reduced testing time and increased the testing motivation of the participants (Piaw, 2011). In addition, added computer examination can increase test security, provision of instant scoring, better use of professional time, reduced time lag, greater availability, greater accuracy, greater standardization, greater control, greater utility with special students and groups, longterm cost saving and easier adaptive testing (Kuzima, 2010; Olson, 2013).

Previous studies explained that the integration of computer in examination showed that there is no difference between the test scores achieved in the computer-based test and in the paperpencil based test, also, the preformance of IBT is not affected by the gender of the students (Akdemir and Oguz, 2008; Millsap, 2000; Werhner, 2010; and Baumer, at all, 2009).

However, using computers adopting computer in examination cannot be separated from in cooperating computer in teaching and learning. In this case, there are challenges in using computers in teaching in general classes. Butler and Sellbom (2002) explain that the barriers of using computer in teaching and learning are that sometimes technology has the tendency to become unpredictable. Another problem is that the new technology needs more time to get accustomed to and learn. Moreover, trainings on how to use this new technology should be arranged by the schools' authority. In addition, computer based examination does not provide immediate feedback. Furthermore, if the number computers are limited for the number of examination, the examination has to be held in more than one session (Kuzima, 2010 p. 194). In this case, even the positive response shows towards the computer-based test, in some cases examinees may also prefer paper-based test as well (Jamil, Tariq, and Shami, 2012). 


\section{Computer Based Implementation in NE in Indonesia}

The first implementation of Computer based in NE was in 2014 in Indonesian Schools in Singapore and Kuala Lumpur. The consequence of implementing of Computer Based in NE has encouraged improving the literacy of students in ICT (Information and Communication Technology). Furthermore, in 2015 the Computer Based in National Examination has involved 555 schools in Indonesia. Furthermore, in 2016 there are about 4,000 schools that have registered to implement Computer Based National Examination. It has encouraged the government to increase the number of schools that can implement the Computer Based National Examination in the next year (Kemendikbud RI, 2015).

There are some points that include as the special requirements for school that intend to implement CBNE:

1. Provide person in charge of computer lab (proctor and technician).

2. Provide the computer facilities in terms of server and clients

3. Internet network is with bandwidth minimum 1 Mbps.

4. Local Area Network - LAN that switch to $10 / 100 / 1000$ Mbps with the number of port based on the number of computer for each server.

However, in the implementation of CBNE in Indonesia, some schools face some barriers such as low speed of the internet whereas the size of course modules that should be downloaded is about 35 GB. In addition, the electricity of Indonesia is sometimes interrupted because of insufficient supply. However, the CBNE has benefits in terms of decreasing the fraud cases, more efficient, and can reduce the cost that is used for National Examination (Harmiyuni and Sailan, 2016).

\section{School Administration System in Indonesia}

In terms of school administration in Indonesia, there is ministry regulation Number 24, year 2008 that is followed by the school administration. Based on that regulation, there are three main positions that a school must have; the head of administration, executives affairs and school special services officers. They must have standard national qualification to have this position. Their qualification was also based on the level of school they are from. For example, the minimum qualification of head administration for secondary school is bachelor degree with four years working experience in the related field. Furthermore, executive affairs were divided into eight divisions; employee affairs, treasures, infrastructure and facilities affairs, public relations, secretary, students' affairs, curriculum divisions and general executive affairs (Menteri Pendidikan Nasional Republik Indonesia, 2008).

In addition, the Ministry of Education, Indonesia also designed the standard of management in school based on the government regulation Number 19, year 2007 (Menteri Pendidikan Nasional Republik Indonesia, 2007). There are six main elements in establishing a rule in a school; Program Planning, The implementation of plan, Supervising and evaluation, School principal and leadership, Management Information System, and Special assessment (Menteri Pendidikan Nasional Republik Indonesia, 2007).

In the implementation of CBNE, the main person who is in charge is the proctor of the school, and other teams will be under the head of administration. Usually, the proctor and technician will be a person who is good in computer skill, and they also IT teacher in the schools.

\section{RESEARCH METHOD}

The methodology for conducting this study follows the steps of qualitative research methods by involving three different types of school; Eneral secondary high school (SG1), Vocational 
Secondary high school (SV2) and Boarding senior high school (SB3). In addition, these schools has implemented Computer Based National Examination in 2016. To obtain the answer for research questions, the researcher conducted an interview with the school principal of each school. In this case, the school principals are as the informant in this study.

Table 1: Schools Profile

\begin{tabular}{|c|c|c|c|c|c|c|}
\hline $\begin{array}{l}\text { School } \\
\text { code }\end{array}$ & Type of school & Status & $\begin{array}{l}\text { Year of the CBNE } \\
\text { implementation }\end{array}$ & Location & $\begin{array}{l}\text { Internet } \\
\text { Access }\end{array}$ & $\begin{array}{l}\text { Electric } \\
\text { Source }\end{array}$ \\
\hline SG1 & $\begin{array}{l}\text { General } \\
\text { Secondary high } \\
\text { school }\end{array}$ & Public & 1 year & Town & Non & PLN \\
\hline SV2 & $\begin{array}{l}\text { Vocational } \\
\text { secondary high } \\
\text { school }\end{array}$ & Public & 2 years & Town & $\begin{array}{l}\text { Telkom } \\
\text { speedy }\end{array}$ & $\begin{array}{l}\text { PLN and } \\
\text { diesel }\end{array}$ \\
\hline SB3 & $\begin{array}{l}\text { Secondary } \\
\text { boarding school }\end{array}$ & Public & 2 year & Rural & $\begin{array}{l}\text { Telkom } \\
\text { astinet }\end{array}$ & PLN \\
\hline
\end{tabular}

The instrument used in this study was a set of interview questions for the school principals. The instrument begins with the basic description of the school. Its interview questions were divided into four sections which are related to the research question of this study; infrastructures and facilities, human resources, government support and administration role.

\section{ANALYSIS AND DISCUSSION}

Nik Suryani (2008) Suggested that the procedures of data analysis should involve (i) organizing data; (ii) generating categories, themes and patterns; (iii) focusing analysis and (iv) emerging hypothesis testing. For data analysis, the researcher followed a few stages such as; (i) the data are collected from the interview session was transcribed verbatim, (ii) Interview transcription and document's data were translated into English. Then, the translated version were, (ii) coded and (iii) labelled to the same codes and grouped together into meaningful categories.

\section{Educational Benefits}

One of the elements in the schools' vision and mission is related to the integrity of National Examination. CBNE can potentially reduce cheating during National Examination and increase its integrity (Kuzima, 2010, \& Oslon,2013). Furthermore, CBNE has benefits in reducing the paper usage as the examination booklet does not need to be printed (Piaw, 2011), and CBNE does not need a large number of invigilators as much fewer number of examination rooms were in use. As a result, it can reduce the allocated budget to pay the honorarium for the invigilator. Long-term cost saving is included as one of the benefits integrating computer in the examination. It is because the facilities of computerised examination can be used for future examinations as well (Kuzima, 2010).

On the other hand, CBNE does not need too many rooms for the examination, as they can manage three sessions of the examination. In paper based National Examination (NE), there are about 20 students in one examination venue. It means that if a school has 200 students who will sit for NE, then the school needs to prepare about 10 classrooms for the examination. Meanwhile, as the CBNE can be managed into three sessions, the school only needs about three classrooms for the examination. As a result, the school does not need more invigilators for CBNE as compared to the paper-based NE.

However, managing more than one session of computer based examination was included as one of disadvantages by Kuzima (2010). He mentioned that sometimes the number of 
computer is limited to the number of the students. As a result, schools are forced to have more than one sessions of the examination. This can be further studied whether managing more than one session can be included into the advantages or disadvantages of integrating computer in the examination.

Moreover, the purpose of implementation of CBNE is to increase students' computer literacy. In the first year of CBNE implementation in Indonesia school in Singapore and Kuala Lumpur, MoEC of Indonesia also claimed that CBNE can help to increase students' computer literacy (kemdikbud, 2016).

\section{Facilities, infrastructure and human resource management}

There are three main items to consider in preparing for the Computer Based National Examination; computer facilities, examination room, and generator set. In terms of computer facilities, server and computer client are included as the main tools in implementing CBNE. In the implementation of NE in 2016, these schools were able to provide computers client and server for three sessions of examination. Based on the regulations of the Ministry of Education and Culture, one server can access 35 client computers. Then, those 35 client computers were placed into one room. It means that one CBNE examination venue could accommodate a total of 35 students.

In addition, examination room and generator set are additional requirements which were not included in the requirement list by the ministry. To implement CBNE, it is mentioned that there were special rooms which were not school computer labs that were used as the examination room. On the other hand, generator sets were prepared as additional electric supply power if sudden power outage happens during the examination.

In terms of human resource, schools provide two persons; proctor and technician. Proctor is the person who has the responsibility to handle the server while the technician is the person who has responsibility in examination room such as making sure all the computers in the examination room have uninterrupted internet access. This is based on the regulation that is established by the Ministry of Education and Culture, Indonesia in terms of CBNE implementation. The proctor and technician were teachers in that school who teach Information and technology subject. It means that, there are no designation staffs who are the proctor and technician. In addition, it was also found that one school assigned the same person to handle both job scopes during the examination.

\section{Budget allocated management}

In order to implement CBNE successfully, the procedure of budget allocation is also part of school administration. Budget that the schools got was allocated to purchase the computer units, servers and for the honorarium of the proctors and technicians. In addition, the budget was also allocated to repair the faulty computers. It was found that there was a school that stated the budget that they got was not enough as they needed to repair some faulty computers. As a result, this school used additional school budget Biaya Operasional Sekolah (BOS) which is not included as the budget for implementing CBNE.

\section{Management of Examination}

During its implementation, the selected schools conducted three sessions of examination from $8.00 \mathrm{am}$ to $10.00 \mathrm{am}, 12.00 \mathrm{pm}$ to $02.00 \mathrm{pm}$ and $04.00 \mathrm{pm}$ to $06.00 \mathrm{pm}$. This kind of system adopted as the number of client computers were not enough for the number of students. As the result, they could not conduct one session of examination. On the same situation was depicted in a study by Kuzima (2010), which has mentioned that one of disadvantages of computer 
based examination is that if the schools do not have enough computers, they are forced to conduct the examination in more than one sessions.

In addition, based on the interviews, it was found that schools that implemented CBNE must find the accessible time to download the examination booklet. The accessible time that was mentioned was at dawn. Then, the password to open the examination booklet was sent just 15 minutes before the examination was supposed to start.

\section{Simulation and Trainning}

For the implementation of CBNE, simulation and training were given to the students, proctors, technicians and teachers. The students were involved in the CBNE simulation exercise before the actual CBNE took place in order to develop the skills in answering the NE items. On the other hand, the school provided such trainings to the teachers, proctorsand technicians in meeting and sharing session or MGMP about the procedures of CBNE. MGMP stands for Musyawarah Guru Mata Pelajaran which is a kind of meeting of teachers of particular subjects from different schools in order to share and solve any problem that is related to any particular issue in school. Proctor and technician from different schools also gathered together for discussing the procedure of CBNE in their own schools.

\section{Community Involvement}

In terms of community involvement, parents, non-formal institutions, university and Perusahaan Listrik Negara (PLN) were also involved in the implementation of CBNE. Students' parents were given the instruction about the procedure of CBNE. It was expected that the parents can remind their children about this new examination system. Non-formal institution has a role in terms of providing try-out of NE for students. They support the schools that wanted to conduct try-out by providing examination items. Furthermore, the university provided a trainer for schools that want to conduct the training for teachers. Finally, PLN played an important role in terms of providing electric supply during the examination. Also, they lent the generator set for schools to mitigate the possibility of any power outage that happened suddenly.

\section{CONCLUSION AND RECOMMENDATIONS}

As CBNE is a new examination model in Indonesia, the Ministry of Education should provide more support including financial assistance and non-financial assistance to the schools in Indonesia. In addition, MoEC should provide training for the teachers in terms of computer orientation. The purpose of training is to increase theachers'skills in handling CBNE. It will also address the shortage of proctors and technicians required for handling CBNE sessions. Furthermore, the ministry also should support the schools in the rural areas by providing good school facilities especially in terms of CBNE implementation. This is to help the rural schools to avoid any technical difficulties faced while implementing CBNE.

Schools are recommended that to achieve the purpose of CBNE, school principal and administration are required to enhance the human resources in terms of the number of proctor and technicians. This is to ensure that all the technicians and proctors arte honestly covering their job scopes before, during and after examination. Furthermore, schools' principal and administration must develop equipments in their schools especially for CBNE implementation. In this case, providing more client computers and serversis required in order to avoid multiple examination sessions. In addition, Teacher training has to be conducted for the teachers who teach subjects that are examined through NE. Training should include lessons for enhancing their computer operating skills as well. In this case, every try-out for students should be 
conducted by implemented CBT in order to habituate the students before the actual examination.

\section{References}

Akdemir, 0., \& Oguz, A. (2008). Computer-based testing: An alternative for the assessment of Turkish undergraduate students. Computers \& Education, 51(3), 1198-1204.

Baswedan, A.R. (2015). Kebijakan Perubahan Ujian Nasional. (Power Point Slide). Retrieved from: http://kemdikbud.go.id/kemdikbud/dokumen/un2015/UjianNasional2015Konpers\%20Mendikbud.pdf

Baumer, M., Roded, K., \& Gafni, N. (2009). Assessing the equivalence of Internet-based vs. paper-and-pencil psychometric tests. In D. J. Weiss (Ed.), Proceedings of the 2009 GMAC Conference on Computerized Adaptive Testing.

Butler, D. \& Sellbom, M. (2002). Barriers to adopting technology for teaching and learning. Educause Quarterly, 2, 22-28.

Harmiyuni, \& Sailan, M. (2016). Persepsi Siswa Tentang Pelaksanaan Ujian Nasional Berbasis Komputer Di SMK Komputer Mutiara Ilmu Makassar. Jurnal Tomalebbi, (2), 36-42

Jamil, M., Tariq, R.H., \& Shami, P.A. (2012). Computer-Based VS Paper-Based Examinations: Perceptions of University Teachers. The Turkish Online Journal of Educational Technology 11(4), 371-381

Joshua, M. T., \& Ikiroma, B. (2012). Computer-Based testing in Nigeria's university entrants' matriculation examination: Readiness and acceptability of critical stake-holder. Retrieved from http://www.iaea.info/documents/paper_371f29eed.pdf

Kemendikbu RI. (2015). Ujian Nasional Berbasis Komputer. Retrieved from http://unbk.kemdikbud.go.id/

Kemendikbu RI. (2016). Buku Saku UN. Jakarta: Kementerian Pendidikan dan Kebudayaan Nasional Repulik Indonesia.

Kemendikbu RI. (2016). Ujian Nasional Berbasis Komputer. Retrieved from http://ubk.kemdikbud.go.id/

Kuzmina, I. P. (2010). Computer-based testing: advantages and disadvantages. Journal NTU-KPI. Philosophy. Psychology. Pedagogy, (1), 2010-1.

Menteri Pendidikan Nasional. (2007). Standar Pengelolaan Pendidikan Oleh Satuan Pendidikan Dasar Dan Menengah. Indonesia: Peraturan Menteri Pendidikan Nasional Republik Indonesia Nomor 19 Tahun 2007

Menteri Pendidikan Nasional. (2008). Standar Tenaga Administrasi Sekolah/Madrasah. Indonesia: Peraturan Menteri Pendidikan Nasional Republik Indonesia Nomor 24 Tahun 2008.

Millsap, C. M. (2000). Comparison of computer testing versus traditional paper-and- pencil testing. Unpublished doctoral thesis, University of North Texas, Texas

Nurfuadah, R.N. (2014). Ujian Nasional dari Masa ke Masa. Okezone News. Retrieved from http://news.okezone.com/read/2014/12/30/65/1085698/ujian-nasional-dari-masa-ke-masa

Olson, T. (2013). Utilizing Online Exams and Human Resources to Improve Student Learning and Minimizing Academic Dishonesty-Finds From Large Section Deployment. In International Conference on e-Learning (p. 321). Academic Conferences International Limited.

Piaw, C. Y. (2011). Comparisons between computer-based testing and paper-pencil testing: Testing effect test scores testing time and testing motivation. In Proceedings of The Informatics Conference (pp. 1-9).

Werhner, M. J. (2010). A comparison of the performance of online versus traditional on-campus earth science students on identical exams. Journal of Geoscience Education, 58(5), 310-312. 